\title{
A Survey of Determinant of Access to Informal Credit by Small Businesses in Meru County, Kenya
}

\author{
Kirimi Eliphas Titus ${ }^{1}$, Guyo S. Huka ${ }^{2}$ \\ ${ }^{1,2}$ Meru University of Science and Technology
}

\begin{abstract}
Research has shown that one of the challenges facing small scale businesses is access to formal and informal credit. General rules and regulations in the formal financial institutions hold that the poor are not bankable since they cannot afford the required collateral, and hence considered not credit-worthy. This research intended to contribute towards this end by investigating the factors that determine access to informal credit by small scale businesses in County, Kenya. The purpose of this study was to generate a profile of the factors affecting access to informal credit by the small businesses, with the aim of shedding some light on specific financial challenges these businesses are facing. The factors that were investigated in this research are whether collateral, interest rate, level of education and the poverty level limits access to informal credit. Using descriptive survey design and purposive sampling technique 60 businesses people were selected from 10 Small shopping centres in Egoji Divisions of Meru County. A structured questionnaire was used to collect data from the sample respondents. It has been established that there was a weak relationship between the amount borrowed and the level of education of the borrower, there was strong relationship between the amount borrowed and the interest rate charged $\left(R^{2}=0.838\right)$, that and there was a negative relationship between poverty and the amounts borrowed.
\end{abstract}

Key Words: Credit, Access to capital, poverty levels

\section{Introduction}

Micro and Small Enterprises (MSEs) are businesses in both formal and informal sectors. These enterprises cut across all sectors of the Kenyan economy and provide one of the most prolific sources of employment creation, income generation and poverty reduction. The sector contributes up to $18.4 \%$ of the country's Gross Domestic Product (GDP) and employs $72.4 \%$ of all persons in the country (Government of Kenya, 2005).

However, despite the sector's importance in the growth of the economy, it faces many constraints including limited access to finances. Financial institution perceive MSEs as high risk ventures and commercially unviable. This phenomenon has made it difficult for MSEs to graduate into medium and largescale enterprises, thus making the country have a weak base for industrial take-off and sustainable development (Adams, D. W. 1992).

According to Haugen (2005), despite of an increased in supply of formal credit in rural areas of Kenya, informal lenders remain the dominant source of credit for the poorest households. Sundharam (1996) indentifies some advantages of informal money lenders which include flexibility and immediately availability of finances, minimum amount of paper-work and official requirements as well as physical proximity to the borrower enabling frequent contact.

\subsection{Statement of the Problem}

MSE have become an important contributor to the Kenyan economy. The sector contributes to the national objective of creating employment opportunities, training entrepreneurs, generating income and providing a source of livelihood for the majority of low-income households in the country accounting for 12$14 \%$ of GDP (Republic of Kenya, 2003). With about $70 \%$ of such enterprises located in rural areas, the sector has a high potential for contributing to rural development.

The demand for credit for productive investments usually from small enterprises that are less riskaverse and enables them to overcome liquidity constraints, making it possible to undertake investment that can boost production, employment and income creation. Research further points out that credit for consumption purposes can have a long term positive impact on household productivity, allowing acquisition of skills or improvement in health status if such loans are used for education or health care. These may enhance or at least preserve the productivity of the labour force.

Despite the role they play, Credit Institutions, Commercial banks and other formal institutions fail to cater for the credit needs of smallholders, mainly due to their lending terms and conditions (Rosemary 2001). It is generally the rules and regulations of the formal financial institutions that have created the myth that the poor 
are not bankable, and since they can't afford the required collateral, they are considered uncredit-worthy (Aredo, D. 1993).

According to rosemary (2001), it is clear that policies and strategies designed to boost credit and finance for small businesses have been formulated in the absence of number significant variables. These key variables are reliable information on MSE, financing methodologies, data on the magnitude of the MSE sector, characteristics of MSE operators, and factors influencing the growth and dynamics of the sector among others. The situation translates into high credit transaction costs, for collecting and verifying available information, mainly on the creditworthiness of MSE borrowers. Informal credit is therefore imperfect substitute of formal borrowing to the small scale business holders. This research intends to contribute towards this end by finding out some of the major factors influencing the access to informal finance by small businesses.

\subsection{Objectives of the Study}

The overall objective of this study was to analyse the factors that affect the access to informal credit by the small-scale businesses. The specific objectives are:

1. To investigate the relationship between the interest rate and the amount of credit.

2. To find out the relationship between education and the amount of credit borrowed.

3. To investigate the relationship between poverty and amount of informal credit borrowed.

Research Hypotheses

$\mathrm{Ho}_{1}$ : There is no relationship between the rate of interest and the amount of credit acquired.

$\mathrm{Ho}_{2}$ : There is no relationship between level of education and the amount of credit borrowed.

$\mathrm{Ho}_{3}$ : There is no relationship between poverty level and the amount of credit borrowed.

\section{Literature Review}

Interest rates, level of education of the borrowers and poverty level of the borrowers have been identified as key factors that may have critical influence on access to informal credit by MSE. Interest rate is a price in the credit market and is essentially a monetary policy tool for checking demand and supply relationship for credit. In Kenya, the high rates can partly be attributed to the government's heavy involvement in the sector. Furthermore, the lending rate increases with the 'perceived' risk by the lender. Another key factor in financial success is financial education (Bell, C. 1990). Financial education programs impart knowledge, skills and attitudes required to adopt good management practices for earning, spending, saving, borrowing and investing. In addition participants in these programs become equipped with information and tools to make better financial choices, work towards their financial goals and ultimately enhance their economic well-being.

The Kenya Economic Recovery Strategy for Wealth and Employment Creation (2003) notes that education is a key determinant of earnings and therefore an important exit path out of poverty. Education improves peoples' ability to take advantage of opportunities that can improve their well-being and to participate in economic activities. The report adds that higher education attained by an individual can reduce his chances of being poor by taking advantage of opportunities such as credit for business.

\section{Empirical Literature}

According to National Micro and Small Enterprises Baseline Survey in Kenya (1999), youth willing to go into business are disadvantaged due lack of access to credit facilities. Aleem (1990), in a study of informal market lenders and their clients in Chambar in Pakistan, argued that informal lenders mainly used their established relationship with borrowers as a screening mechanism. Lenders did not generally entertain loan requests from people who had not had previous dealings with them either in the form of the sale of harvested output through them or purchase of farm inputs. The longer the period of the previous business relationship, the higher will be the probability of the borrower getting credit access.

Evidence by Kochar (1997) also suggested that the probability of access to informal credit is positively and significantly influenced by whether personal guarantees are given for informal loans. This result may be explained in terms of personal guarantees serving as alternative collateral that is valued by informal lenders. Haugen Norunn (2005) in his Study of Default and Informal Lending in Nepal established that powerful landowners or lenders had specific preferences with regards to who they want to deal with. This results in a segmented credit market as well as a segmented labour market usually geographically defined.

In addition Haugen (2005) postulates that the market lenders' use of written contracts and the village lenders' criteria for providing loans indicate that there are information problems in these credit markets. Village lenders are better informed about certain borrowers and therefore prefer to lend to them. The market lenders that are not involved in any trade or other business in a village are equally uninformed about all the potential borrowers in the village and have to use other means to overcome the information problems.

In addition Bell C. (1990) in his research found out that no rational borrower could collateralize his property with an intention of losing the asset. Mugambi (2010) argues that collateral minimize repercussion of 
information asymmetries by supplementing the assessment of the borrowers' credit worthiness and by increasing the risk adjusted on the loan given. Nevertheless, Besley and Coate (1991), argue that despite an increased supply of formal credit, informal lenders are still the most important source of credit among the poor. Formal lending institutions often require collateral like land from borrowers. The poorest households are often landless and therefore excluded from formal credit programs.

To concur, Hatlebakk, M. (2000), study reveals that lenders usually rely both on some amount of background checking as well as initial testing loans to screen less risk borrowers from the high risk ones. However, even the minimal or no collateral requirements potentially exclude the poorest from the schemes. In Bangladesh, for example, only one-fourth of all Microfinance clients are among the hard-core poor (UNDP report 2000).

Despite of other findings, Mahabub (1998) study in Grameen bank in Bangladesh reviewed that $61 \%$ of its borrowers were moderately poor and $38 \%$ were extremely poor.

Studies of the informal credit market demonstrate that extremely high informal interest rates were charged on loans to poor individuals. Extensive rural credit programs in the last decades were intended to break the informal lenders anticipated monopoly power in the rural credit markets. Competition was expected to lower the informal interest rates. However, these policies do not seem to have improved the credit terms for the poorest households in rural areas (Haugen 2005).

Moreover, Hoff and Stiglitz (1997) in an investigation of the causes of high interest rates in the informal lending assert that a moneylender is an imperfect substitute for any other moneylender. Therefore, if there is free entry into money lending, the market is appropriately modelled as monopolistically competitive. If the marginal cost of money lending rises for some reason, then the equilibrium interest rate charged will increase.

Hatlebakk, M (2000) argued that interest rate depends on risk related variables like caste, land value and loan size and concluded that there was no significant effect of these variables on the interest rate. In addition, Klonner and Rai (2005) also observed exogenous differences in interest rates in India, where the government introduced interest rate ceiling. They found evidence that default rates are higher when interest rates were higher.

However, Basu (1997) argues that, empirical studies of the credit market in developing countries demonstrate the existence of a dual credit market and prove a gap between formal and informal interest rates charged within the same region. Field experience confirms these findings. It is puzzling that such a set up does not cause arbitrage between the two sectors. Basu continues to argue that if enough people saw this opportunity the informal interest rate would fall and the formal interest would rise until equilibrium is restored. The researcher also investigated the relationship between access to informal credit and the education level of the borrower. Policy makers in Europe and the United States believe that more entrepreneurship is required to reach higher levels of economic growth and innovation. Indeed, empirical research supports positive links between entrepreneurial activity and economic outcomes (Bottomley, Anthony1963). Policy makers also believe that increased levels of entrepreneurship can be reached through education (European Commission, 2006). Therefore, such education is promoted and implemented into school curricula in many of the European member countries (European Commission, 2006) and the United States (Kuratko, 2005).

Moreover, Phan et al (2002) in their study in India found out that this negative relationship between formal education and the propensity to start business may be due to perceptions of risk and the high opportunity cost of human capital. Highly educated people would like to recoup their investments as quickly and as safely as possible making self-employment unattractive. Similarly, Kimuyu and Omiti (2000) study on Kenyan MSEs revealed that the entrepreneur's age and education achievement affect borrowing. They found out that the inclination to borrow increases with the entrepreneur's age and education. Chowdury and Garcia (1993) also affirmed earlier findings in their research in Kenya where reasons given by the poor people for avoiding formal credit are difficulties with illiteracy and high fees charged by officials.

However, on the evidence to reduce vulnerability, the UNDP (2000) claims that the hard-core poor, having few assets, are reluctant to take on the risks of credit, and when they do, it is usually for emergencies and consumption, not for production. Extending financial services to the poorest requires innovations which go beyond those that have been developed so far. In spite this, the provision of microcredit has been found to strengthen crises coping mechanisms, diversify income earning sources, build assets and improve the status of borrowers (Hashemi et al, 1996).

Also, in Pakistan's context, Khan (2001) estimated the economic impact of the financial support program on rural households. He concluded that the economic impact of the support program on rural households is substantially large and probably makes a significant difference to the households close to the poverty line. Hence, he qualified this conclusion by arguing that it holds particularly for those rural households that participate on a sustained basis over a long period. 
However, Morduch (2003) urges that most micro finance schemes charge close to market-clearing interest rates which is enough to ensure full cost-recovery given the high cost per loan of small-scale lending. Such high rates are unaffordable to the core poor given their lack of complementary inputs despite having a smaller amount of capital marginal returns. Hence, he concludes that if the core poor cannot afford high interest rates they will either not take up the service or take it up and get into financial difficulties.

\section{Conceptualization of Research Variables}

The independent variable for this study included interest rates, borrowers' levels of education and poverty levels of the borrowers. The rate of interest is the cost of borrowing. That is the difference between the Amounts paid back less the Principle borrowed from the money lender. Any payments in kind will also be converted into monetary form to arrive at a standard measure of value. The level of education of a borrower was determined using the formal education number of years attained by the respondent. Finally, poverty levels were determined in accordance with the Poverty Reduction Strategy (PRS) Paper whose indicators included household income, number of dependants in the family and the household per-capita expenditure. The conceptual framework of the factors affecting access to informal credit is shown in the figure 2.1

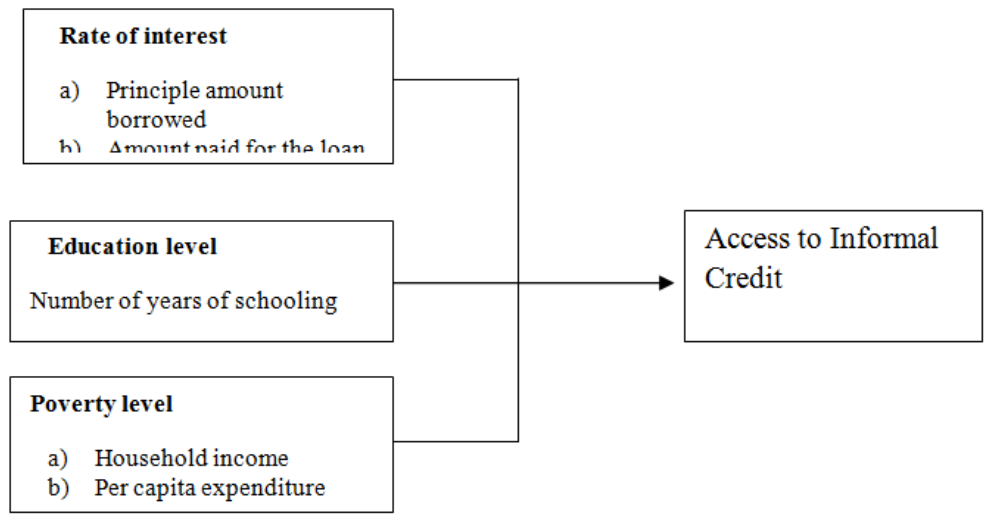

Figure 2.1: A Conceptual Frame Work showing Determinant of Access to Informal Credit by Small Businesses in Meru County, Kenya

\section{Research Methodology}

The researcher employed cross-sectional survey and targeted all the shopping centres and small-scale businesses in Igoji West and East Divisions of Meru County, Kenya. The researcher used Multiple-Stage Sampling techniques in which 6 shopping centres out of the population of 10 shopping centres in Igoji divisions were selected. Then, purposive sampling was used to get a sample of 10 respondents from each shopping centre totalling to 60 respondents. The researcher prepared a questionnaire with short structured and non structured questions which was administered by the researcher with help of enumerators. The data was analysed using SPSS software. A linear regression model was used to define the relationships between the dependent variable (level of education, interest rate and poverty level) and dependent variable (amount of informal credit).

\subsection{Introduction}

\section{Reserach Findings}

In this study there were more small scale businesses owned by women compared to those owned by men. Men owned proportionately less businesses (32\%) than women owning 68\%. Eighty four percent of the respondents were married while $16 \%$ were single while there were no cases of having been divorced, widowed or separated. Concerning age bracket of the business practitioner, the research established a normal distribution of the ages of the business practitioners as shown in figure 4.1 


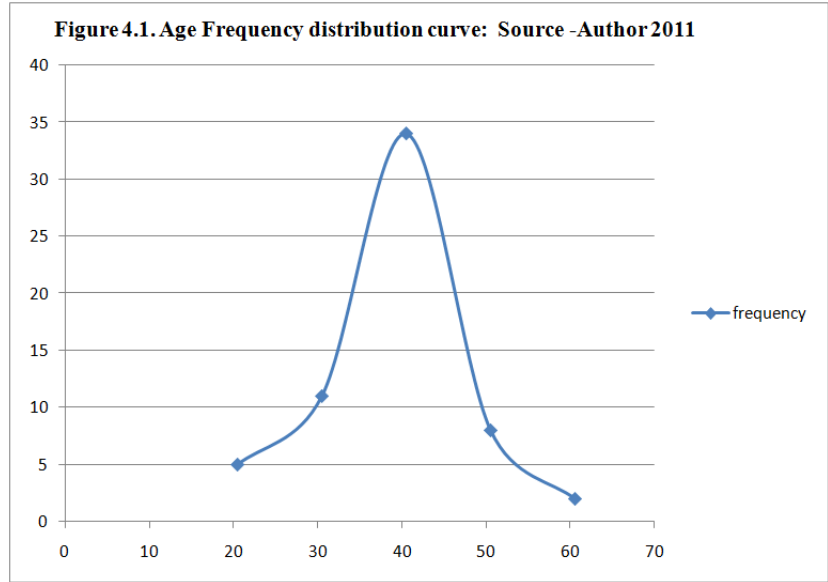

\subsection{Level of Education}

The level of education of the borrowers was based on the number of years of schooling. The researcher found that there was a normal distribution between the level of education and the number of borrowers in each level with most business practitioners being secondary school leavers and none having a degree level of education as shown in figure 4.2

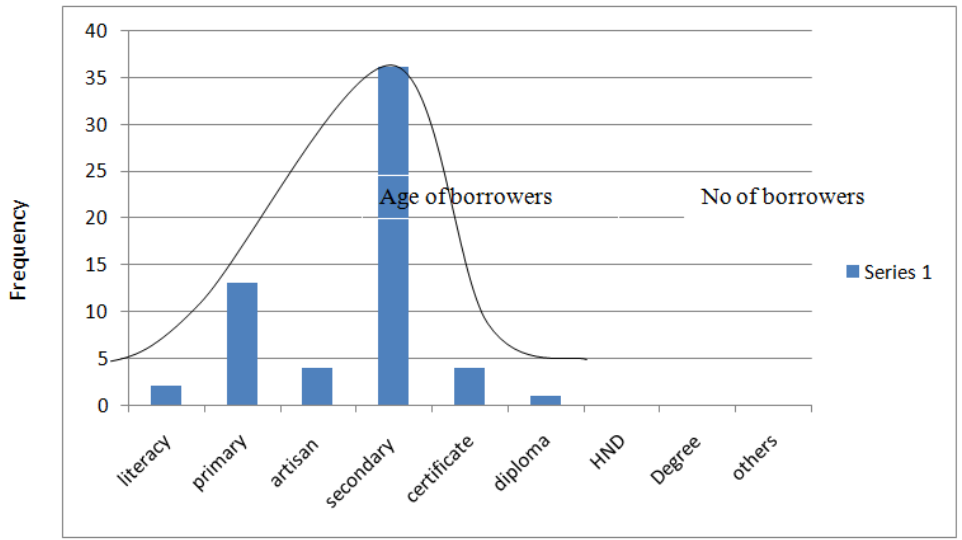

\section{Figure 4.2: Business Practitioners and Levels of Education}

To quantify the level of education the study used the number of years of schooling to determine the education level of the borrower. The product of the frequency and the average years of schooling (f.x) for each amount confirms that high years of schooling correlates to borrowing small amounts from the informal lenders. This does not necessarily mean that the business is for the less educated but could also imply that the educated can access credit from the formal credit market. The results are tabulated table 4.1

Table 4.1 Frequency of borrowers of various amounts and their levels of study

\begin{tabular}{lllll}
\hline $\begin{array}{l}\text { Amount Ksh. } \\
\text { Range }\end{array}$ & $\begin{array}{l}\text { Average } \\
\text { amount }\end{array}$ & $\begin{array}{l}\text { Frequency } \\
\text { (f) }\end{array}$ & $\begin{array}{l}\text { Average } \\
\text { years of } \\
\text { schooling (x) }\end{array}$ & $\begin{array}{l}\text { Total number of } \\
\text { years of schooling } \\
\text { (f.x) }\end{array}$ \\
\hline $500,001-600,000$ & $550,000.5$ & 6 & 12 & 72 \\
$400,001-500,000$ & $450,000.5$ & 5 & 10 & 50 \\
$300,001-400,000$ & $350,000.5$ & 7 & 12 & 72 \\
$200,001-300,000$ & $250,000.5$ & 10 & 13 & 130 \\
$100,001-200,000$ & $150,000.5$ & 12 & 12 & 240 \\
$1-100,000$ & $50,000.5$ & 20 & 13 & 260 \\
\hline
\end{tabular}

Source: Authors (2012)

Simple linear regression on number of years of schooling and the amount borrowed was done. $\mathrm{R}^{2}=$ $0.201<\mathrm{R}^{2}$ critical at a degree of freedom of 59 and confidence level of $95 \%$ the study accepts the null hypothesis that there is no relationship between the level of education and amount borrowed. The finding 
challenges theories such as Phan et al (2002) which suggests that there is a negative relationship between formal education and the propensity to borrow in order to start business.

\subsection{Interest Rates}

The study established that $95 \%$ of business owners (respondents) have borrowed more than three from informal lenders. It can be observed that most borrowers acquire small amounts of money while very few business people borrowed larger amount of loans. Table 4.2 shows the loan amounts borrowed and the number of borrowers from each range of amounts.

Table 4.3 Frequency on the amount borrowed

\begin{tabular}{lll}
\hline Amount range & Average amount & $\begin{array}{l}\text { Frequency/ No. of } \\
\text { borrowers }\end{array}$ \\
\hline $500,001-600,000$ & $550,000.5$ & 6 \\
$400,001-500,000$ & $450,000.5$ & 5 \\
$300,001-400,000$ & $350,000.5$ & 7 \\
$200,001-300,000$ & $250,000.5$ & 10 \\
$100,001-200,000$ & $150,000.5$ & 12 \\
$1-100,000$ & $50,000.5$ & 20 \\
\hline
\end{tabular}

Source: Authors (2012)

The above tabulation was also plotted on a graph to show linearity relationship using frequency distribution as shown in figure 4.3

Figure 4.3 Frequency distribution curve for various amounts borrowed

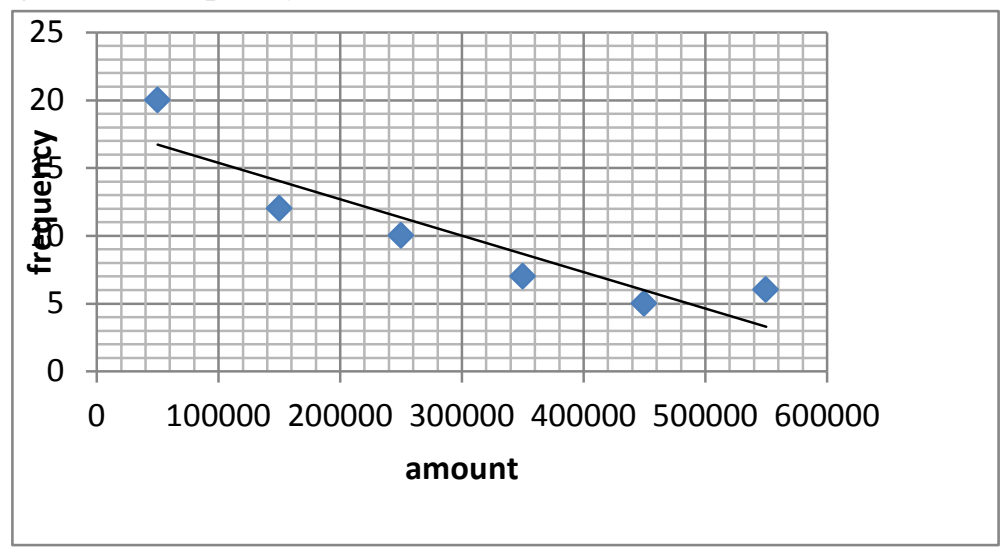

Source: Authors (2012)

Data on interest rate was got by subtracting the total amount paid back from the principle amount borrowed. The data was regressed and a Pearson's square of 0.838 was got. The interest charged is directly proportional to the amount borrowed. Since $\mathrm{R}_{\text {calculated }}^{2}>\mathrm{R}^{2}$ critical the researcher rejects the null hypothesis that there is no relationship between interest rate and the amount borrowed. The data was regressed and the result shows a strong relationship between the amount borrowed and the interest rate required. The findings confirm the competitive view theory which postulates that money lenders charge a high interest as an incentive where collateral is lacking. The regression results are presented in figure 4.6.

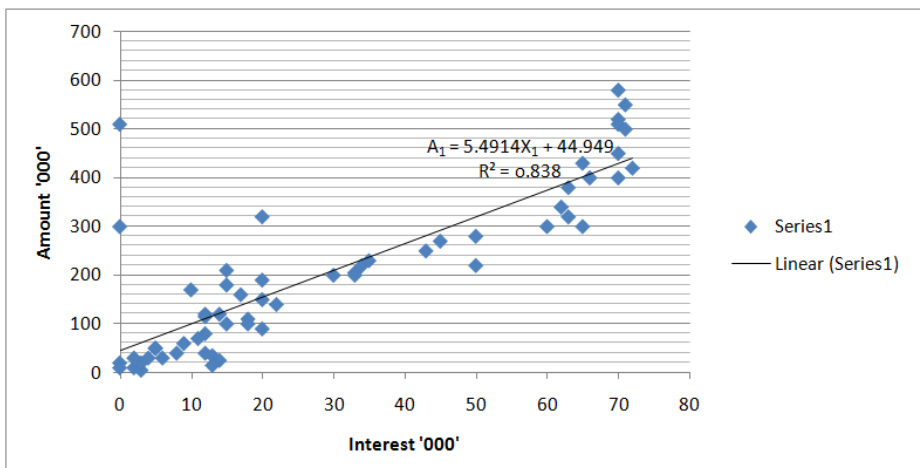

Figure 4.6: Interest Charged for Money Borrowed (Source: Authors, 2012) 


\subsection{Poverty Status}

On the poverty level the researcher used the household per-capita income and the household number of dependants. The household expenditure was divided by the number of dependants to arrive at the household percapita expenditure. If a family was poor it was consuming less than a dollar per-person per day. The information reviews that most of the poor business people borrowed very little amounts. This relationship can also be shown in table 4.3

Table 4.3 Number of the poor businesses people who borrowed various amounts

\begin{tabular}{lll}
\hline Amount borrowed & No. Poor & Not poor \\
\hline $500,000-600,000$ & 1 & 5 \\
$400,000-499,999$ & 0 & 5 \\
$300,000-399,999$ & 4 & 3 \\
$200,000-299,999$ & 5 & 5 \\
$100,000-199,999$ & 8 & 4 \\
$0-99,999$ & 15 & 5 \\
Total & 33 & 27 \\
\hline
\end{tabular}

Source: Authors, (2012)

Simple linear regression was conducted and showed a negative relationship between poverty and the amount of loan borrowed $\left(\mathrm{R}^{2}=0.576\right)$. This confirms earlier theories which postulate that money lenders may exclude the very poor from borrowing again on grounds of repayment risk. This may explain the weakness of micro-finance in reaching the core poor.

\subsection{Multiple Regression Analysis}

The amount of credit borrowed was regressed against the amount of interest charged for credit, the education level of the borrower and the dummy for collateral. Multiple regression model $\mathrm{Y}=\mathrm{a}+\mathrm{bX} \mathrm{X}_{1}+\mathrm{cX}_{2}+$ $\mathrm{dX}_{3}+\mathrm{fX}_{4}+\mathrm{e}$ was used and the results shows the Pearson's $\left(\mathrm{R}^{2}\right)=0.698$. This means that approximately $70 \%$ of the amount borrowed $(\mathrm{Y})$ depends on the independent variables. This is shown in table 4.4. On the other hand the ANOVA test (table 4.5) shows that at a confidence level of 95\% and degree of freedom of 59 the independent variables are statistically significant.

Table 4.4 Model Summary

\begin{tabular}{lllll}
\hline Model & R & r Square & Adjusted R Square & Std. Error of the Estimate \\
\hline 1 & .847 (a) & .718 & .698 & 95756.27198 \\
\hline
\end{tabular}

Source: (Authors, 2012)

Table 4.5 ANOVA

\begin{tabular}{llllll}
\hline & Sum of Squares & Df & Mean Square & f & Sig. \\
\hline Regression & 1285171750688.207 & 4 & 321292937672.052 & 35.040 & $.000(\mathrm{a})$ \\
Residual & 504309499311.793 & 55 & 9169263623.851 & & \\
Total & 1789481250000.00 & 59 & & \\
\hline
\end{tabular}

Source: (Author, 2012)

Predictors: (Constant), Dummy for Poor, Dummy for no Collateral, Education, Interest, and Dependent Variable Amount

Table 4.6 Coefficients

\begin{tabular}{|c|c|c|c|c|c|}
\hline & \multicolumn{2}{|c|}{ Unstandardized Coefficients } & \multicolumn{2}{|l|}{ Standardized } & \multirow[t]{2}{*}{ Sig. } \\
\hline & $\mathrm{B}$ & Std. Error & Beta & & \\
\hline (Constant) & 281764.015 & 59331.966 & & 4.749 & .000 \\
\hline Interest & 3.682 & .623 & .552 & 5.912 & .000 \\
\hline Education & -8121.102 & 4579.087 & -.147 & -1.774 & .082 \\
\hline Dummy for Poor & -103089.625 & 30813.900 & -.297 & -3.346 & .001 \\
\hline
\end{tabular}

Source: (Authors, 2012), Dependent Variable: Amount

Table 4.6 shows that at $99 \%$ confidence level interest rate and the level of poverty are statistically significant, while at $90 \%$ the level of education is also statistically significant. The researcher also utilized simple linear regression to confirm the results.

On the other hand, the researcher Rejects the null hypotheses that there is no relationship between the amount borrowed and the interest rate and accepts the alternative hypothesis. The research observes that there is a strong relationship between the amount borrowed and the amount of interest charged $\left(\right.$ also, $\mathrm{r}^{2}=0.835$, simple linear regression). 
The researcher also accepts the null hypotheses that there is no relationship between the amount borrowed and the education level, therefore rejecting the alternative, since education is not statistically significant at $95 \%$ confidence level. Finally, the researcher rejects the null hypotheses that there is no relationship between the amount borrowed and poverty level. $\left(r^{2}=-0.576\right.$, simple linear regression). Therefore accepts the alternative hypothesis that there is a relationship between poverty level and the amount of credit borrowed.

\section{Conclusion and Recommendation}

From this research it was evident that more than one factor affects access to informal loans by SMEs. There was a strong relationship between interest rate and the amount borrowed. In addition, there was a weak (Statistically not significant) relationship between the level of education and the amount of money borrowed but a strong negative relationship between poverty and the amount borrowed. The research also concludes that this credit market conforms to Pure Risk Premium Theory which postulates that a market without a mechanism of risk reduction through collateral allows lenders to charge an interest to offset the risk of default. Surprisingly there was a paradox that collateral was not required to access informal but the poor still borrowed less than the relatively richer borrowers.

From the research findings, there was need to expand the capacity of informal credit sources to enable them to increase their potential to lend to more SMEs. There is also need for policy framework that affords the necessary incentives for the enterprise growth. Finally, there is need to investigate why the poor borrow less from informal money lenders while collateral was not required as shown by this research.

\section{References}

[1]. Adams, D. W. (1992). Using Contracts to Analyze Informal Finance, Economics and Sociology Occasional Paper No. 1972, Rural Finance Program, Ohio State University, Ohio.

[2]. Aredo, D. (1993). The Informal and Semi-formal Financial Sectors in Ethiopia: A Study of the Iqqub, Iddir and Savings and Credit Co-operatives, AERC Research Paper 21.

[3]. Basu, K. (1997). Analytical Development Economics. The Less Developed Economy Revisited. MIT Press.

[4]. Besley, Timothy. (1994). "How Do Market Failures Justify Interventions in Rural Credit Markets?" World Bank Research Observer.

[5]. Besley, T. and Coate, S. (1991). Group Lending, Repayment Incentives and Social Collateral, Princeton University.

[6]. Besley, T. S, Coate, and G Loury (1993). The Economics of Rotating Savings and Credit Associations. American Economic Review.

[7]. Bell, C. (1990). Interaction between Institutional and Informal Credit Agencies in Rural India. The World Economic Review, Vol. 43 (1990).

[8]. Besley, T. and Coate, S. (1995). Group Lending, Repayment Incentives and social Collateral. Journal of Development Economics.

[9]. Bottomley, Anthony (1963). The Cost of Administering Private Loans in Underdeveloped Rural Areas, Oxford Economic Papers.

[10]. Coate, S. (1993). Reciprocity without commitment. Characteristics and performance of informal insurance arrangements. Journal of Development Economics, Vol. 40.

[11]. Hatlebakk, M. (2000). Will More Credit Increase Interest Rates in Rural Nepal?, in Essays on Poverty in Informal Rural Markets. University of Bergen

[12]. Haugen, N. (2005). A study of Default and Informal Lending in Nepal, a thesis is submitted in the partial fulfilment of a Master degree in Economics University of Bergen,.

[13]. Hoff, K. and Stiglitz, J.E. (1997). Moneylenders and bankers: price-increasing subsidies in a monopolistically competitive market. Journal of Development Economics.

[14]. Hoff, K. and Stiglitz, J.E. (1993). The economics of rural organization; theory, practice, and policy, Oxford University Press, Oxford.

[15]. Hoff, K and J. Stiglitz (1993). A Theory of Imperfect Competition in Rural Credit Markets in Developing Countries, Institute for Policy Reform, Working Paper Series IPR 49, Washington D.C.

[16]. Morduch, J. (2003). Do interest rates matter? Credit demand in the Dhaka slum. New York University

[17]. GoK (2005). Sessional Paper No.2 of 2005 on Development of Micro and Small Enterprises for wealth creation, employment generation and poverty reduction. Government printer. Nairobi. 